\title{
How have after-school clubs adapted in the United Kingdom post-March lockdown?
}

\author{
Pete King ${ }^{1}$
}

\begin{abstract}
After-school clubs have provided an important childcare service for parents and carers where children are provided with an environment to play once the school day has finished. When the United Kingdom went into lockdown in March 2020, all children's services closed that included the childcare provision of after-school clubs. When they reopened in between July and September 2020, changes had to be implemented to meet Government restrictions. This study from 54 respondents working in the childcare sector identified changes within four themes: maintain service; bubbles; play space and play behaviour. This has resulted in an increase hygiene measures, staffing and amount of space for individual children, however, there is a decreased in the number of children attending, the resources and activities on offer and movement within the place space. Although after-school childcare is still being offered, there is financial concern on their viability and sustainability as parental demand may drop which has implications in providing a unique environment where children of different ages and abilities mix.
\end{abstract}

\section{Article History}

Received: 21 April 2021

Accepted: 15 May 2021

\section{Keywords}

After-school club;

Lockdown; COVID-19; Play

\section{Introduction}

Childcare is a service offered in the United Kingdom (UK) with the first recorded childcare provision in 1816 in New Lanark, Scotland set up by Robert Owen (Bradburn, 1966). Childcare within UK law, for example legislation for England and Wales, is defined as:

(2) "Childcare" means any form of care for a child and, subject to subsection (3),

care includes -

(a) education for a child, and

(b) any other supervised activity for a child (Childcare Act 2006, p. 10).

This research study focuses specifically on (b), supervised activity in relation to after-school school club provision where children attend out of school hours whilst parents and carers may require childcare due to support them to work or attend educational or training requirements (King, 2020a). After-school clubs within the UK are mostly run in primary schools but are not linked to the educational curriculum. They are not an after-school activity run by the school or school staff. They are a dedicated recreational time for children to play whilst still on the school premises. After-school clubs focus on supporting children's play (Playwork Principles Scrutiny Group [PPSG], 2005) and are staffed provision run by childcare workers and playworkers.

The number of after-school clubs within the UK saw an increase in the 1990s as a result of two Government initiatives to encourage more adults, particularly women to return back to the workforce (Faulkner \& Coates, 2013). The first was the Out of School Childcare Initiative (OSCI) through the Conservative Government (Education Extra, 1997) and the second was the National Childcare Strategy (Department for Education and Employment [DfEE], 1998) developed by the Labour Government through the New Opportunities Fund (NOF) (BIG Lottery Fund, 2004). The OSCI initiative begin in 1993 and 
provided funding by the Conservative Government's Department for Education and Employment through local Training and Enterprise Councils (TEC), whereas the NOF was through the BIG National Lottery charity, both providing set up grants for sustainable childcare provision. The after-school club were:

"designed to provide a safe haven for children after-school, with play, rest, recreation and stimulating activities within a high quality care setting for which parents pay a fee" (Education Extra, 1997, p. 11)

The sustainability of the provision was primarily based on parents and carers paying a fee for their children to be cared for at the end of the school day and during school holidays. At its height in the early 2000s, it was estimated from around 350 clubs in 1990, the number of after-school clubs in England rose to an estimated 5000 (Barker et al, 2003), which also included the introduction of breakfast clubs and wraparound care. Although there has been a decline in the number of after-school clubs due to a combination of set up funding not in existence and the result of austerity measures being introduced by the new Conservative and Social Democrat Party (SDP) collation Government in the UK in 2008, 79\% of families in England in 2017 had used some form of childcare during the school term (Department for Education [DoE], 2017) which would include an after-school club. In addition to providing childcare as parents and carers worked, children attending after-school clubs were spending much of their free time outside of school playing in these adult supervised settings and have taken these memories of play into adulthood (King, 2020b).

After-school clubs continue to provide childcare for adults and a safe space for children to play in their childhood. However, in March 2020, the UK Government announced a national lockdown (Dickson, 2020) resulting in the closure of schools to all except for those who were kept open specifically for children of key workers and vulnerable children (King, 2021). A qualitative study using semi-structured interviews undertaken at the start of lockdown on how playwork and childcare provision responded identified three themes: provision stopped where staff were furloughed; provision continued supporting the school 'hubs' and provision had to adapt to a different way of operating (King, 2021). To support key workers, the UK Government instructed Local Authorities to implement a 'cluster or hub model' (UK Government, 2020). A cluster or hub is one location where any key working children can be educated and looked after whilst their parents and carers undertake a key working role, for example, a doctor. Most hubs were situated in schools, although other venues such as family centres were used, however these were only accessible for families of keyworkers. The closing of adventure playgrounds, afterschool clubs impacted on both the children who attended, and the staff employed to support children's play (King, 2021).

The themes of provision closing, supporting 'hubs' for key workers and being adaptable were supported by a quantitative online survey undertaken by the Out of School Alliance (OOSA) (2020a) in England. During the first national lockdown in May 2020, from 359 after-school clubs, $82 \%$ of them were temporarily closed and just $13 \%$ remained open to support key workers children. The closure of the afterschool club was mostly by either not financially viable to remain open or the school was providing the childcare as a function of running as a 'hub'. Two follow up studies undertaken by the OOSA in August (2020b) identified from 620 clubs, 72\% still remained closed and by November (2020c) found from 313 afterschool clubs, $51 \%$ (just over half) were running with reduced numbers of children attending. It was also noted that between the August and November survey's, there were half the number of respondents and this was put down to clubs having to close (OOSA, 2020c). In Scotland, the Scottish Out of School Network (SOSCN) re-opening survey in October 2020 found from 103 responses, 91\% of clubs were operating with less numbers compared to pre-lockdown in March.

In the UK, from the first lockdown in March 2020, support for childcare providers had been provided by the Scottish Government for staff who have been furloughed who could apply for funds under the Coronavirus Job Retention Scheme (UK Government, 2021a). In addition to the funding for furloughed staff, the UK Government also provided funding support for small businesses, which many after-school clubs operate as (UK Government, 2021b). There has also been additional funding support in Scotland for childcare providers who remain open for keyworking and vulnerable children under the 'Temporary Restrictions Fund' (Scottish Government, 2021). In Wales, any childcare provision affected by the coronavirus can also apply for a COVID-19: Childcare Provider Grant (Welsh Government, 2021) and the 
Childcare Support (Cwtch) Grant under the ‘ERF Restrictions Business Fund' (Business Wales, 2021). There is worry that as small businesses, after-school clubs will stop operating as they rely on fee paying parents and carers (OOSN, 2020c; SOSCN, 2020).

The focus of after-school clubs has been to provide a safe space to play whilst their parents and carers continue to work or study. Play, and particularly free play is recognized to be important in children's development (Santer, Griffiths, \& Goodall, 2007; Zosh et al., 2017). Recent research has shown that within the primary schools within the UK, children's recess time has decreased (Baines \& Blatchford, 2019; Ramstetter, Murray, \& Garner, 2020), so reducing the amount of play during the day. Although there has also been a decline in the number of children attending after-school clubs in the last 10 years in the UK (Baines \& Blatchford, 2019), for many children who still attend them, the after-school club can provide both the time and space to play with other children and still have an important informal role in their development (Zosh et al., 2017). What the after-school club also provides is a unique provision where children aged often between 4 and 11 years can play and socialize together, where the provision supports the five fundamental types of human Play: physical play, play with objects, symbolic play, pretense, or socio-dramatic play, and games with rules (Whitebread, Basilio, Kuvalja, \& Verma, 2012) where children have more control over their play. Research has indicated the nature of after-school clubs empowers children and contributes to their informal learning (Smith, 2010). With the lockdown in March 2020 causing all after-school clubs to close, this not only had a financial implication for the staff but there is also the consideration of the effect this may have on children deprived of an important space for them to play.

The importance of after-school club provision has shown they provide a place for children to meet their peers, make friendships and engage in a variety of play activities (Barker et al., 2003; Beunderman, 2010). Although not part of the school educational curriculum, after-school clubs can provide an important 'addition' to the school by providing a safe space for children to play whilst their parents and carers are still at work when the school day finishes. After-school clubs provide an essential service to the community and may be considered as a developing 'Community of Practice' (CoP) (Wenger-Trayner \& WengerTrayner, 2015), particularly in areas of deprivation (Callanan et al., 2016) as evident in other child related services as adventure playground (King \& Newstead, 2020). The impact of COVID-19 and lockdown is already a concern for children's education (McGuinness, 2021), and this can also include other aspects of children's lives, for example being able to meet and play with friends within the after-school club in their recreation or free time (Dodd, 2021).

After-school clubs provide an important service for both children and their parents and carers. This study is a follow up study to the March study on how after-school clubs operated during lockdown (King, 2020c) to find out how after-school clubs have managed to operate since lockdown finished in July 2020 and the new school term in the UK began in September 2020. This formed the basis of the research question 'How have after-school clubs operated post-March lockdown?'

\section{Method}

An open-ended online survey was constructed using the Qualtrics ${ }^{\circledR}$ platform with ethical approval granted from the College of Human and Health Sciences Ethics Committee, Swansea University. The survey asked whether participants considered themselves to be a childcare worker, a playworker or both. The participants stated their job role from manager, co-ordinator, senior practitioner, practitioner, volunteer or director. The location of the after-school club was provided in relation to where in the UK and the type of building it is located in (e.g. school). Participants then stated what happened to the provision during lockdown from closed and being furloughed, closed but still working, opened for keyworking children, open for both keyworking and vulnerable children and open for all children. The responses from these questions provided demographic data.

Participants were provided with $\mathrm{x}$ open-ended questions to provide qualitative narrative data:

- Describe a typical day at the after-school club before lockdown?

- How has the after-school club run since it re-opened? 
- What new policies and procedures have had to be put in place since post-lockdown?

- How did the children play when they returned to the after-school club after lockdown?

- What changes to your practice has there been since post-lockdown?

- How has social distancing been implemented in the after-school club?

- Is there anything you would like to add or say?

The survey was piloted with five experienced professionals in the play and childcare sector. Feedback was positive with minor changes in wording, the only significant change was the addition of whether the participant considered themselves both a childcare worker and playworker. The online survey was circulated through a link and posted on various social media platforms including Twitter ${ }^{\circledR}$ and Facebook ${ }^{\circledR}$ from September 2020 to December 2020 and circulated to local and national out of school networks who distributed the link to their members.

All responses from the open-ended questions were analysed using the Nvivo $12 ®$ software for analysis. The analysis used the thematic analysis framework developed by Braun and Clarke (2006) which is a six-step process to develop initial codes to form themes.

\section{Participants}

In total 130 people clicked the survey link. Out of the 130, 3 stated they were under 18 years or age so were not able to take part in the survey, 2 responses were from adventure playgrounds so the data was not used and 71 respondents did not provide any information. This left 54 responses where the data was used for this study.

When asked if they considered themselves a playworker, childcare worker or both, 25 (48\%) stated they were playworkers, $6(12 \%)$ were childcare workers and $21(40 \%)$ stated there were both. The responses showed $33(61 \%)$ were managers, $11(20 \%)$ directors, $5(9 \%)$ senior practitioners, $3(6 \%)$ practitioners and 2 $(4 \%)$ co-ordinators reflecting a range of different roles and responsibilities within the after-school club. The majority of responses were from England with 45 responses (85\%), 6 from Wales (11\%) and 2 from Scotland $(4 \%)$. Most after-school clubs were situated in a school with 36 responses $(67 \%)$, followed by other at 13 $(24 \%), 4$ in a community centre $(7 \%)$ and 1 in a village hall $(2 \%)$.

\section{Results}

Graph 1 shows how the variation on how the after-school clubs operated during the March to July 2020 Lockdown:

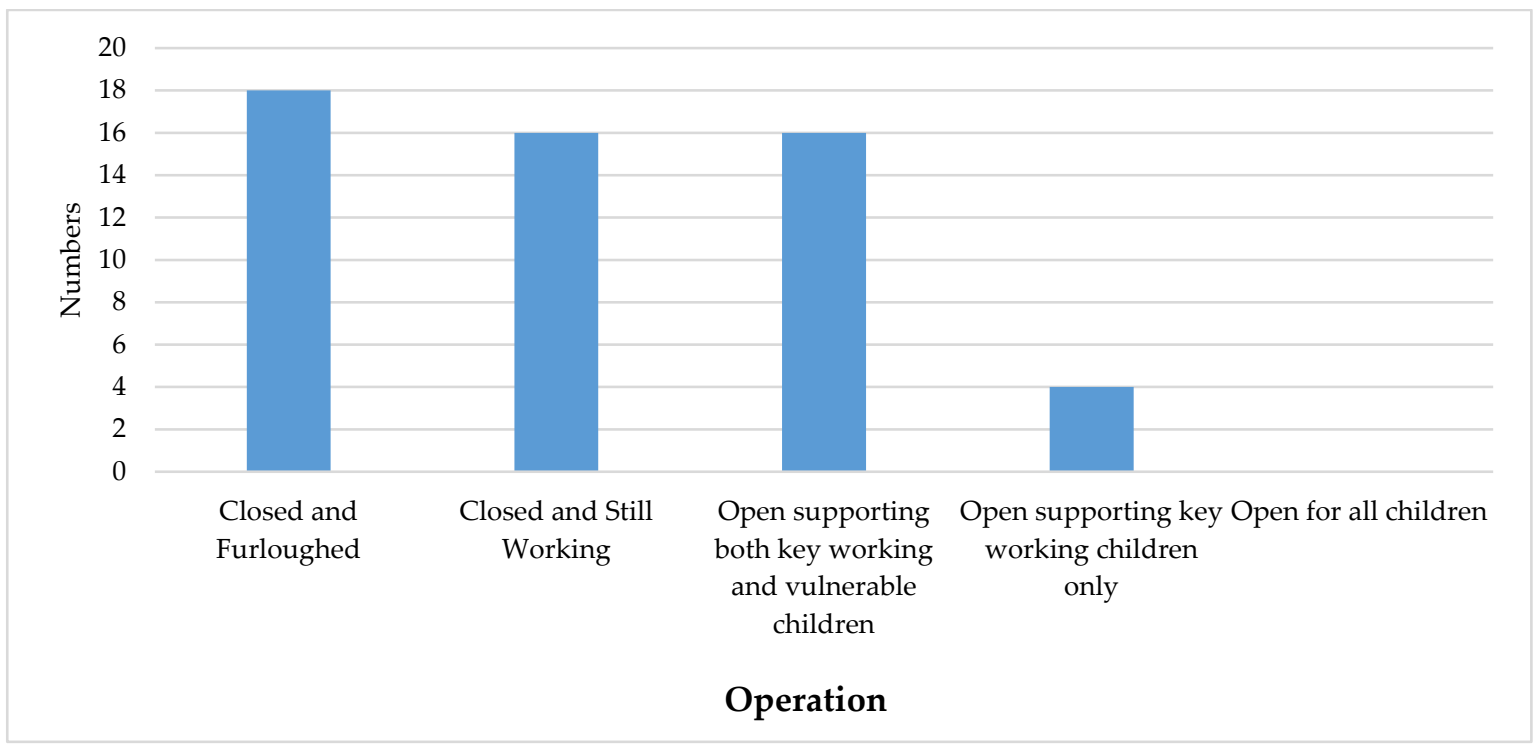

Graph 1. How after-school clubs operated between March and July 2020 
Graph 1 shows that 34 after-school clubs (63\%) were closed where the staff member was either furloughed, or still working but not running any sessions. Where the provision was still running, 16 places (33\%) were supporting both key working and vulnerable children whilst 4 (7\%) were catering for key working children only, presumably all supporting the school 'hubs'.

\section{A ‘Typical' Day Before Lockdown}

When asked to describe a 'typical' day before lockdown, the comments provided from the survey respondents are shown in Table 1 and reflect the after-school club type provision:

Table 1. A 'typical' after-school club session

\begin{tabular}{|c|c|c|c|c|c|c|}
\hline Time & Provision & Age Range & Number & Snack & Space & Activities \\
\hline $\begin{array}{l}\text { Staff arrive } \\
\text { before the } \\
\text { sessions start to } \\
\text { set up, organise } \\
\text { activities, } \\
\text { prepare food } \\
\text { and do any } \\
\text { paperwork } \\
\text { Clubs start at } \\
\text { the end of the } \\
\text { school day } \\
\text { (around 3pm) } \\
\text { and run up to } 6 \\
\text { pm }\end{array}$ & $\begin{array}{l}\text { School-based after-school } \\
\text { clubs collect reception } \\
\text { children up to year } 2 \text { from } \\
\text { classrooms or their } \\
\text { schools. Children in Y3 } \\
\text { upwards can make their } \\
\text { own way. Some offer } \\
\text { wraparound care } \\
\text { (breakfast and after-school } \\
\text { club) and holiday } \\
\text { playscheme } \\
\text { For school-based clubs } \\
\text { with children from other } \\
\text { schools, or non-school } \\
\text { based after school club, all } \\
\text { children are collected from } \\
\text { their schools. }\end{array}$ & $\begin{array}{l}\text { 4-11 however } \\
\text { key was } \\
\text { children } \\
\text { 'mixing } \\
\text { together' and } \\
\text { not being } \\
\text { segregated into } \\
\text { age groups }\end{array}$ & $\begin{array}{l}\text { Range } 20 \\
\text { to } 160 \\
\text { with } 30-40 \\
\text { around } \\
\text { average }\end{array}$ & $\begin{array}{l}\text { Mostly } \\
\text { cold snack } \\
\text { where } \\
\text { children } \\
\text { can self- } \\
\text { select }\end{array}$ & $\begin{array}{l}\text { Both indoor } \\
\text { space and } \\
\text { outdoor space } \\
\text { is available } \\
\text { which is } \\
\text { supervised }\end{array}$ & $\begin{array}{l}\text { Mixture of } \\
\text { organised } \\
\text { activities and } \\
\text { resources } \\
\text { available to } \\
\text { choose from. } \\
\text { Child-led, } \\
\text { free-flow } \\
\text { play, free } \\
\text { play }\end{array}$ \\
\hline
\end{tabular}

The 'Typical' day for an after-school shown in Table 1 has not changed much in relation to the structure and emphasis of being a child-led provision (King, 2000). The common use of phrases such as free play and free-flow play (Bruce, 1994) where children can choose what, where and how they want to play within the confinements of after-school clubs. Children have the movement of using both indoor and outdoor space, although there would be adults supervising these areas all the time. These confinements include having to be supervised, not allowing to leave if they get bored and provision having to adhere to any registration and inspection regulations. Another aspect that was stated was 'mixing together' children, which provides a unique feature for school-based after school clubs as during the school day children will stay within their peer and age groups, however in the club children do mix together (King, 2000).

Table 2. An after-school session post-lockdown

\begin{tabular}{|c|c|c|c|c|c|c|}
\hline Time & Provision & Age Range & Number & Snack & Space & Activities \\
\hline $\begin{array}{l}\text { Staff arrive } \\
\text { earlier more } \\
\text { staff needed } \\
\text { and allocated } \\
\text { 'bubbles' }\end{array}$ & $\begin{array}{l}\text { Children } \\
\text { collected in } \\
\text { their year } \\
\text { groups }\end{array}$ & $\begin{array}{l}\text { 4-11 and } \\
\text { children now } \\
\text { kept in 'bubbles' } \\
\text { in year groups } \\
\text { reflecting the } \\
\text { school }\end{array}$ & $\begin{array}{l}\text { 'Bubbles' } \\
\text { of } 15 \\
\text { children }\end{array}$ & $\begin{array}{l}\text { Children } \\
\text { either bring } \\
\text { snack from } \\
\text { home or is } \\
\text { made }\end{array}$ & $\begin{array}{l}\text { Both indoor space } \\
\text { and outdoor space is } \\
\text { available which is } \\
\text { supervised and } \\
\text { children stay in their } \\
\text { 'bubbles' }\end{array}$ & $\begin{array}{l}\text { Resources fixed } \\
\text { within 'bubbles' } \\
\text { and cleaned } \\
\text { before another } \\
\text { 'bubble' uses } \\
\text { them. }\end{array}$ \\
\hline & & & & & & $\begin{array}{l}\text { Less freedom of } \\
\text { movement and } \\
\text { choice of activities }\end{array}$ \\
\hline
\end{tabular}

A more detailed description of how the after-school clubs have been able to operate is shown from the thematic analysis can be shown in Table 3, where four main themes are considered: Maintain Service; Bubbles; Play Space and Play Behaviour. 
Table 3. Themes and sub-themes

\begin{tabular}{|c|c|c|}
\hline Theme & Sub-Theme & Main Points \\
\hline \multirow{3}{*}{ Maintain Service } & Revise Policies & $\begin{array}{l}\text { All operational policies and procedures amended (Health and Safety, } \\
\text { Safeguarding, registrations forms etc.) } \\
\text { COVID-19 Policy } \\
\text { Risk Assessment }\end{array}$ \\
\hline & Increase Hygiene & $\begin{array}{l}\text { Cleaning of resources } \\
\text { Change in collection and pick-up routine } \\
\text { No parents/carers on site access }\end{array}$ \\
\hline & Financial Concerns & $\begin{array}{l}\text { Reduce numbers as parent demand decreases either not working or } \\
\text { working from home } \\
\text { Furloughed Staff during lockdown } \\
\text { Extra staffing costs forming bubbles } \\
\text { Restricted Government Funding making sustainability uncertain }\end{array}$ \\
\hline \multirow{3}{*}{ Bubbles } & Designated Groups & $\begin{array}{l}\text { Year Groups } \\
\text { Class Groups } \\
\text { Key Stage Groups }\end{array}$ \\
\hline & Designated Staff & $\begin{array}{l}\text { Enough staff for number of bubbles } \\
\text { Staff remain } 2 \mathrm{~m} \text { apart within and between bubbles }\end{array}$ \\
\hline & Regulated Movement & $\begin{array}{l}\text { Bubbles Kept Apart } \\
\text { No Social Distancing within bubbles }\end{array}$ \\
\hline \multirow{3}{*}{ Play Space } & Re-arrange physical space & $\begin{array}{l}\text { How snack time is arranged and implemented } \\
\text { Specific room or allocated space for bubbles } \\
\text { Increased children's individual space }\end{array}$ \\
\hline & $\begin{array}{l}\text { Designated Resources and } \\
\text { Activities }\end{array}$ & $\begin{array}{l}\text { More structured and less freedom to choose how to play } \\
\text { Less equipment and rotated between bubbles } \\
\text { Some physical activities not allowed }\end{array}$ \\
\hline & Increase outdoor use & $\begin{array}{l}\text { Safer to be outside } \\
\text { Children are encouraged to play outside } \\
\text { Restricts types of play as not indoors }\end{array}$ \\
\hline \multirow{3}{*}{ Play Behaviour } & As before & $\begin{array}{l}\text { Children happy to be back } \\
\text { Adapt to changes }\end{array}$ \\
\hline & Challenging & $\begin{array}{l}\text { Frustrated with new restrictions in place } \\
\text { Nervous at first } \\
\text { Friends, peers and siblings can't play together outside of their bubble }\end{array}$ \\
\hline & Social Interaction & $\begin{array}{l}\text { Increase in staff and children interaction } 1: 1 \text { interaction } \\
\text { Reduce physical contact between children and with staff }\end{array}$ \\
\hline
\end{tabular}

\section{Theme1: Maintain Service}

Theme 1 focuses on how after-school clubs have continued to provide a service. This required a complete revision of all policies and procedures resulting in developing a new COVID-19 policy and risk assessment:

COVID-19 policy which covers - health and safety, safeguarding, play, registration and induction, risk assessment, payment (Respondent no. 17).

The revision of all the policies and procedures resulted in an increase in hygiene which not only involved cleaning of equipment, but a change in how children were brought to the club and where and when they were collected which prohibited access for parents and carers:

Adults collecting children ring doorbell when arriving, and a member of staff then takes child to the exit of school where parent/carer collects them. No adults allowed into setting (Respondent no. 22).

The increase in cleaning costs, the drop in parental need for the provision and where children were put into bubbles, the maintenance of existing number of staff or in some cases increase staffing has put a considering financial burden on the after-school clubs. This is reflected in the comment below: 
We are operating on a shoestring budget due to needing more staff for less children and operating bubbles (Respondent no. 8).

\section{Theme 2: Bubbles}

The theme of 'bubbles' reflected the biggest change to practice. The bubbles formed placed children in designated group, often reflecting the school's year, class or key stage groupings. In addition, staff were allocated specific bubbles:

The segregation of children into bubbles is the biggest headache for me. I am lucky that we have always worked with surplus staff. This means I now have enough staff to support each bubble (Respondent no. 13).

The formation of specific bubbles resulted in staff having to remain $2 \mathrm{~m}$ apart from each other and the children, however, for children within the bubbles, social distancing was not strongly adhered to, although, children between bubbles could not mix together:

Some have found it difficult not being able to play with friends from other key stage bubbles or only being able to be with those from their own key stage. Adults must social distance. Under 11's are not expected to. Activities (more structured) are set up to support and advocate social distancing (Respondent no. 34).

\section{Theme 3: The Play Space}

The main focus of an after-school club is to facilitate a space for children to choose how they want to play. However, with the formation of bubbles and the increase hygiene this resulted in the re-arrangement of the play space in relation to the rooms being used, providing snack and increase use of the outdoor space:

Tables are arranged in rows facing one way. Staff prepare the snack and take in to the children. We try to make it a bit more fun by the staff taking the children's snack 'order' (Respondent no. 16.)

We feel it is safer to be outside and have been surprised how much some of the children, who would normally stay inside given the choice, are enjoying being outside (Respondent no. 29).

However, with the number of children in each bubble at a maximum of 15 and bubbles being in different rooms or rotated where specific activities may take place, this has increased the amount of space children have to play within their bubble:

More room was needed so it was easier to spread out (Respondent no. 2)

Although there was an increase in individual space for each child, the choice of activities within the play space was reduced as resources and activities were either stopped or allocated to specific bubbles at a time:

Limited choice of activities each day due to quarantining toys, games and activities where wiping down is not an option to ensure virus spread is limited" (Respondent no. 9)

\section{Theme 4: Play Behaviour}

Children returned to the after-school club, unless a designated key worker or vulnerable child, after three months of lockdown. The interaction between children and staff were impacted on the introduction of bubbles, staff having to social distance and reduced choice, however although some children found this a challenge to start, it was noted how they quickly adapted and for most, were happy to be back among their friends:

The children were very happy to return but the excitement and lack of contact for so long affected their behaviour towards each other (Respondent no. 17).

The children seemed to have adapted very well. They seemed pleased to be back and seemed to enjoy the interaction within their own groups (Respondent no. 31).

A summary of the results shows: 
- Prior to the March-Lockdown, after-school clubs had a distinct structure where children of all ages can mix together during snack and when they played they had choices on how and freedom to move where they wanted to play

- Post March-Lockdown, the structure of the after-school club had changed in relation to the collection at the start and end of the session and the creation of 'bubbles' reducing the number of children who attended. Children's choice of play and freedom to move was restricted as well as who they could play with

- Thematic analysis on the changes between pre- and post-March lockdown identified four themes: Maintaining Service; Bubbles; Play Space and Play Behaviour

\section{Conclusion and Discussion}

Play has been considered an important aspect for children's development (Zosh et al., 2017), and particularly their free play (Santer et al., 2007) where children can have more choice and variety in their play. With the reduction of school recess time in the UK (Baines \& Blatchford, 2019), the after-school club has become for some children in the UK an important provision to be able to play.

Across the UK, after-school provision has provided a space for children to play after the school day offering childcare whilst parents and carers are able to work. They have become a common feature in many schools, however there is concern for childcare services continuing as a result of the current COVID-19 pandemic reflected in the following comment:

After 22 years my business may not re - open due to COVID 19. I worked hard to build up my business over the years. I feel a sense of despair and loss as there is nothing I can do about it. It is a sad day for all us child carers/playworkers (Respondent no. 20).

This study reflects the statistical evidence provided by current childcare surveys (OOSA, 2020a, 2020b, 2020c; SOSCN, 2020) where clubs that have managed to still run are doing so with reduced numbers in bubbles, staffing issues and reduced space and resources. There is a clear uncertainty of demand for the future, especially as the completion of this research is undertaken during the third national lockdown in the UK.

The rise of after-school clubs in 1990's was a result of the Government's OSCI initiative to get adults (predominately women) 'economically active' and provide a space for children to be looked after when the day finishes. With an uncertain economy in relation to more adults home working and supporting during lockdown children home schooling, this has put huge pressure on after-school clubs to continue as they are run as a business and rely on fee paying parents. The short-term financial help currently available needs to develop into long-term support for this needed provision.

The importance of after-school clubs is not just for the benefit of providing childcare for parents and carers, they provide a unique space for children to play and interact. The universal opinion that play supports children's development (Whitebread et al., 2012) and the role school recess allows for children to have free play (Santer et al., 2007), for example, during recess during the school day (Baines \& Blatchford, 2019). Here, children in primary schools tend to stay in their year groups, both in lessons and during their time in recess, although current research in the UK. However, when coming to the after-school club, children between an age range of 4-11 years mix together, and form friendships where research has shown this is an important factor for attending after-school provision (Barker et al., 2003, Beunderman, 2010). It can be argued that after-school clubs provided this Vygotskian approach to play with mixed ability and age of children is a strong feature of this type of childcare provision. A study on using mixed-age classes within primary school early years education in Ireland indicated a positive impact on learning and wellbeing (Kerr, Murphy, \& Doherty, 2016) and empowerment (Smith, 2010). However, with the change of children in age or class 'bubbles' has resulted in children not being able to mix as freely as they did, in addition to the reduced freedom of movement and choice of activities, and thus potentially on children's development as well as their wellbeing with less play opportunities and not engaging in the five important types of play (Zosh et al., 2017) as there were restrictions on what the after-school club could provide. 
Another aspect to consider is the loss of a play space for children of mixed ages, and abilities to play together, supervised by staff supporting and not controlling their play. How we play in childhood are memories we take into adulthood. A study undertaken by King (2020b) asking adult who attended an after-school club between 1990 and 2010 identified four key factors they remembered playing in this provision. These were the activities that were on offer, the supervising adults, the food provided, and friendships made. These positive memories reflect the 'structure' or most after-school clubs and also highlights the importance of the supervising adult there to support children in their play. The friendships made were in the mixed age range playing together, a unique factor of after-school clubs. During the school day, most children stay and play within their peer and year groups. However, when attending an afterschool club, children of all ages mix and play together.

The current restrictions have reduced children forming friendships outside their bubbles and can only interact with designated staff in their bubbles. Even the providing of a snack is more controlled, and in some cases children have to bring in their own snack to eat in the after-school club at the end of day. One positive consideration is staff recognized they sometimes had more time to play with individual children within the bubbles, something not often being able to do prior to the March Lockdown. There needs to be a follow up study on finding out children's perception's of these changes in their after-school club that are happening now, as this can impact on their memories of attending when they become adults (King, 2019).

There are limitations to this study in relation to a sample of 54 which would appear small compared to the number of after-school clubs across the UK. However, the findings from this qualitative study do reflect, and compliment the quantitative survey's undertaken by two childcare networks (OOSA, 2020a, 2020b, 2020c; SOSN, 2020) where a larger number of respondents took part and provide credibility of the findings (Shenton, 2004). This study was a cross-sectional study undertaken after the first lockdown in March 2020. Subsequently there have been two more lockdowns in the UK in October 2020 and January 2021. Further studies are needed on how after-school are going to survive, particularly with a staggered return to education for primary children, and the uncertainty of new strains of COVID-19 resulting in further lockdown.

This study provided a historical snapshot on how childcare provision of after-school clubs have managed to stay operating post-March 2020 lockdown in the UK. Although after the first lockdown, the different countries within the UK introduced slightly different measures, the result was the same for all after-school clubs. The measures put into place has resulted in the increase of hygiene measures and the restricting of how after-school clubs operate resulting in less parental contact, reduced number of children in year or class bubbles and less opportunities in their choice of play, reduced movement within the play space, and to mix with children of different ages. The reduced numbers of children in bubbles have resulted in more space for children to play and in some cases, more time to interact and play with the childcare staff. However, the overall worry is the financial future for after-school provision in relation to reduced numbers attending due to having smaller 'bubbles' of children and whether parents and carers still need the service.

\section{Declarations}

Acknowledgements: There are no acknowledgements.

Authors' contributions: This is the sole work of the author.

Competing interests: No competing interests.

Funding: No funding was provided for this study.

\section{References}

Baines, E., \& Blatchford, P. (2019). School break and lunch times and young people's social lives: A follow-up national study. Retrieved from https://www.nuffieldfoundation.org/wp-content/uploads/2019/05/Final-report-School-break-and-lunch-times-and-youngpeoples-lives-A-follow-up-national-study.pdf 
Pete KING

Barker, J., Smith, F., Morrow, V., Weller, S., Hey, V., \& Harwin, J. (2003). The impact of out of school care: A qualitative study examining the views of children, families and playworkers. Nottingham: Department for Education and Skills.

Beunderman, J. (2010). The impact of staffed play provision on children, families and communities: A research report written by Demos for Play England. Retrieved from http://www.playengland.net/wp-content/uploads/2015/09/people-make-play.pdf

Big Lottery Fund. (2004). New opportunities fund policy directions for the financial year ending 31 March 2004. Retrieved from https://www.tnlcommunityfund.org.uk/media/documents/pub pol directions nof04.pdf?mtime=20190110124319\&focal=no $\underline{\text { ne }}$

Bradburn, E. (1966). Britain's' first nursery infant school. The Elementary School Journal, 67(2), 57-63.https://doi.org/10.1086/460337

Braun, V., \& Clarke, V. (2006). Using thematic analysis in psychology. Qualitative Research in Psychology, 3(2), 77-101. https://doi.org/10.1191/1478088706qp063oa

Bruce, T. (1994). Play, the universe and everything?. In J. R. Moyles (Ed.), The Excellence of play (pp.189-198). Buckingham: Open University Press

Business Wales. (2021). ERF restrictions business fund. Retrieved from https://businesswales.gov.wales/coronavirus-advice/

Callanan, M., Laing, K., Chanfreau, J., Paylor, J., Skipp, A., Tanner, E., \& Todd, L. (2016). The value of after school clubs for disadvantaged children. Briefing paper 3. Retrieved from https://eprint.ncl.ac.uk/file_store/production/232456/3BDEE6A8-646B-4EE8-B01FED0C672C21C6.pdf

Childcare Act (2006). Retrieved from https://www.legislation.gov.uk/ukpga/2006/21/pdfs/ukpga_20060021_en.pdf

Department for Education and Employment. (1998). Metting the Childcare Challenge. Green Paper. London: HMSO.

Department for Education. (2017). Childcare and early years survey of parents in England, 2017. Retrieved from https://assets.publishing.service.gov.uk/government/uploads/system/uploads/attachment_data/file/669857/SFR73_2017_Tex t.pdf

Dickson, A. (2020, March 23). Boris Johnson announces coronavirus lockdown in UK. POLITICO. Retrieved from https://www.politico.eu/article/boris-johnson-announces-coronavirus-lockdown-in-uk/

Dodd, H. (2021). Letter to Rt Hon Gavin Williamson MP. Retrieved from http://www.reading.ac.uk/web/files/newsandevents/PlayFirst_Letter_Feb21.pdf

Education Extra. (1997). Out of school childcare initiative: Succeeding out of school. London: Department for Education and Employment.

Faulkner, D., \& Coates, E. A. (2013). Early childhood policy and practice in England: Twenty years of change. International Journal of Early Years Education, 21(2/3), 244-263. https://doi.org/10.1080/09669760.2013.832945

Kerr, K., Murphy, C., \& Doherty, A. (2016). "It is through others that we become ourselves." A study of Vygotskian play in Russian and Irish schools. International Research in Early Childhood Education, 7(2), 129-146.

King, P. (2000). The wokingham out of school club demonstration project: A child-centred approach to running a school-based after school club. Reading: Children's Information Centre.

King, P. (2020a). Childcare in the UK. In D. J. Edwards \& S. Best (Eds.), The textbook of health and social care (pp. 170-183). London: SAGE.

King, P. (2020b). (2020): Adult Memories of Attending After-School Club Provision as a Child Between 1990 and 2010, Child Care in Practice, 1-13. https://doi.org/10.1080/13575279.2020.1792839

King, P. (2020c). Can playwork have a key working role?. International Journal of Playwork Practice, 1(1), Article 7. https://doi.org/10.25035/ijpp.01.01.07

King, P. (2021). The impact of COVID-19 on playwork practice. Child Care in Practice, 1-17. https://doi.org/10.1080/13575279.2020.1860904

King, P., \& Newstead, S. (2020). Demographic data and barriers to professionalisation in playwork. Journal of Vocational Education $\mathcal{E}$ Training, 1-14. https://doi.org/10.1080/13636820.2020.1744694

McGuinness, A. (2021). COVID-19: Longer school days, shorter summer holidays and five-term years all under consideration, says education secretary. Retrieved from https://news.sky.com/story/covid-19-longer-school-days-shorter-summer-holidays-and-five-termyears-all-under-consideration-says-education-secretary-12238622.

Out of School Alliance. (2020a). Survey results: Impact of coronavirus on OSCs. Retrieved from https://www.outofschoolalliance.co.uk/downloads/Coronavirus-survey-results.pdf

Out of School Alliance. (2020b). Impact of COVID-19 on OSCs: Follow-up survey. Retrieved from https://www.outofschoolalliance.co.uk/downloads/Covid-Survey-results-Aug2020.pdf

Out of School Alliance. (2020c). Impact of Covid-19 on OSCs: Follow-up survey. Retrieved from 
How have after-school clubs adapted..

https://www.outofschoolalliance.co.uk/downloads/Provider-Survey-Nov20.pdf

Playwork Principles Scrutiny Group. (2005). Playwork principles. Retrieved from https://www.playwales.org.uk/login/uploaded/documents/Playwork\%20Principles/playwork\%20principles.pdf

Ramstetter, C. L., Murray, R., \& Garner, A. S. (2020). The crucial role of recess in schools. Journal of School Health, 80 (11), 517-526. https://doi.org/10.1111/j.1746-1561.2010.00537.x

Santer, J., Griffiths, C., \& Goodall, D. (2007). Free play in early childhood: A literature review. London: Play England.

Scottish Government. (2021). Coronavirus (COVID-19): support to childcare sector. Retrieved from https://www.gov.scot/publications/coronavirus-covid-19-support-to-childcare-sector/pages/transitional-support-fund-forchildcare-providers

Scottish Out of School Network. (2020). Re-opening survey October 2020 results: Out of school care workforce statistics. Retrieved from https://soscn.org/downloads/research/reopening-survey-oct-2020.pdf

Shenton, A. K. (2004). Strategies for ensuring trustworthiness in qualitative research projects. Education for Information, 22(2), 63-75. https://doi.org/10.3233/EFI-2004-22201

Smith, H. H. (2010). Children's empowerment, play and informal learning in two after school provisions (Unpublished doctoral dissertation). Middlesex: Middlesex University,

UK Government. (2021a). Support for businesses and self-employed people during coronavirus. Retrieved from https://www.gov.uk/guidance/claim-for-wage-costs-through-the-coronavirus-job-retention-scheme

UK Government. (2021b). Support for businesses and self-employed people during coronavirus. Retrieved from https://www.gov.uk/guidance/claim-a-grant-through-the-coronavirus-covid-19-self-employment-income-support-scheme

UK Government. (2020). Cluster and hub provision: Coronavirus (COVID-19). Retrieved from https://www.gov.uk/government/publications/using-clusters-and-hubs-to-maintain-educational-provision/cluster-and-hubprovision-coronavirus-COVID-19

Welsh Government. (2021). Business funding and support: coronavirus. Retrieved from https://gov.wales/business-funding-and-supportcoronavirus

Wenger-Trayner, E., \& Wenger-Trayner, B. (2015). Introduction to communities of practice. Retrieved from https://wengertrayner.com/wp-content/uploads/2015/04/07-Brief-introduction-to-communities-of-practice.pdf

Whitebread, D., Basilio, M., Kuvalja, M., \& Verma, M. (2012). The importance of play: A report on the value of children's play with a series of policy recommendations. Retrieved from https:/www.csap.cam.ac.uk/media/uploads/files/1/david-whitebread--importance-of-play-report.pdf

Zosh, J. M., Hopkins, E. J., Jensen, H., Liu, C., Neale, D., Hirsh-Pasek, K, Lynneth S. L., \& Whitebread, D. (2017). Learning through play: A review of the evidence. Retrieved from https://www.legofoundation.com/media/1063/learning-through-play web.pdf 